\title{
The Influence of Knowledge Management Practices on Organizational Performance: The Case of Public Service and Human Resource Development Bureau SNNPR, Ethiopia
}

\author{
Jemila Hussen* Genet Belete \\ Department of Public Management, Ethiopian Civil Service University, Ethiopia
}

\begin{abstract}
The use and management of organizational knowledge has become a commercial obligation to gain competitive advantage. Knowledge is one of the major strategic resources in addition to the traditional factor of production such as labor and capital. Therefore, the aim of this study is to examine the influence of knowledge management practice on organizational performance. The data used for this study was collected from employees of Public Service and Human Resource Development Bureau in Southern Nations Nationalities and Peoples Region (SNNPR) with the total sample size of 118 , and employees were selected by applying systematic random sampling technique. The study used Pearson correlation and simple regression to analyze the data. The results of the study revealed that, all knowledge management practices significantly and positively influences organizational performance.
\end{abstract}

Keywords: Knowledge, Knowledge Management, Organizational Performance, SNNPR

DOI: $10.7176 / \mathrm{IKM} / 10-6-01$

Publication date:September $30^{\text {th }} 2020$

\section{Introduction}

In the current environment which is characterized by continuous change, technological innovations and increasing customer demand, numerous business and academic experts suggest that organizations have to be knowledge driven. The use and management of organizational knowledge has become a commercial obligation to gain competitive advantage since knowledge is one of the major strategic resources in addition to the traditional factor of production such as labor and capital (Choi, Poon, \& Davis, 2008; Yalew, 2011). The widely held belief that the richest resource of today's organizations is the knowledge residing individually and collectively among their employees reflects the importance of processes for promoting the creation, sharing, and leveraging of knowledge (Irma Becerra-Fernandez, 2001)

Thus, many organizations have been forced to rethink the way they manage their knowledge resource and therefore the need for knowledge management. Knowledge management provides processes and technologies to identify, create, represent, and distribute knowledge for reuse, awareness, and learning across the organizations (Fiseha, 2015). The function of knowledge management allows an organization to leverage its information resources and knowledge assets by remembering and applying experiences. As a result, many public and private organizations in well-developed and developing countries are designing and implementing knowledge management practices in order to be competitive and meet the increasing customer demands. However, organizations suffer from difficulties in evaluating performance of their knowledge management practices ( $\mathrm{Yu}$, Kim, \& Kim, 2004).

In line with this Eftekharzadeh (2008) stated that, the evolution and implementation of knowledge management practices is still in its infancy stage in most developing countries. Similarly, Omar Sharifuddin SyedIkhsan and Rowland (2004) suggest that, relatively little empirical research has been conducted in the public sector, and even less in developing countries. Most Prior empirical researches were conducted in private manufacturing industries and the health sector in the developed countries. Due to these facts, there has been a call for empirical researches in the area of knowledge management in developing countries. Hence, this study will investigate the effect of knowledge management practices on organizational performance in public sector organizations specifically in the South Nations, Nationalities and Peoples' Regional (SNNPR), Ethiopia.

\section{Theoretical background}

\subsection{Knowledge Management Practices and organizational performance}

According to Kianto, Ritala, Spender, and Vanhala (2014), knowledge management practices refers to a more practical and perceptible level of research. Knowledge management includes four key steps these are creating knowledge, knowledge codification, knowledge sharing and knowledge utilization. Knowledge creation is the entry of new knowledge into the system and includes knowledge development, discovery and capture (Mohayidin, Azirawani, Kamaruddin, \& Margono, 2007). Knowledge codification is concerned with the practices of codifying or storage of new knowledge and other terms that are being used are organized, store, retention, preservation and documentation (Kianto et al., 2014). Knowledge Sharing is the flow of knowledge from one source like a person, 
group or organization to the other includes activities such as communication, translation, conversion, filtering and rendering (Bratianu \& Bolisani, 2015). knowledge utilization the practices the use and reuse of stored knowledge to bring solutions to problems, reduce the knowledge gaps and inform decision making (Becerra-Fernandez and Sabherwal (2014). However, the study will focus on the first three knowledge manage practices only.

Organizational performance is the degree to which an organization realizes its goals (Zheng, Yang, \& McLean, 2010). Commonly, researchers have utilized both non-financial and financial metrics to measure firm or organizational performance (Khan, 2010). financial measures are sales, profit, and market share while nonfinancial measures efficiency, quality, productivity, satisfaction, intention to quit, and commitment. However, scholars such as Hoskisson, Eden, Lau, \& Wright, (2000) claimed that it is difficult to use financial measures in developing economies due to absence of market-focused and accurate financial reporting and insufficient regulatory mechanism and enforcement about financial reporting. In order to get reliable relationship result, it is better to choose performance indicators which can be influenced by the respective independent variable. Based up on the above discussion, this study conceptualizes organizational performance from innovation and creativity, service quality improvement, employee satisfaction, and turnover intention.

The assumption underlying the practice of knowledge management is that by locating and sharing useful knowledge, organizational performance will improve. Zack, McKeen, \& Singh, (2009) stated that knowledge management influence many different aspects of organizational performance simultaneously. Knowledge management has been linked positively to non-financial performance measures such as quality, innovation, and productivity.

\subsection{Empirical literatures}

The literature is full with studies that examine knowledge management impacts on organizational performance. For instance, empirical study conducted by Kiessling, Richey, Meng, \& Dabic, (2009) among firms in Croatia suggests that knowledge management positively affects organizational outcomes of firm innovation, product improvement and employee improvement. Similarly, Fugate, Stank, \& Mentzer, (2009) empirically examined the importance of knowledge management processes to operational and overall organizational performance. Accordingly, results collected in a logistics operations context prove the existence of a strong positive relationship between a knowledge management process and operational and organisational performance. Tanriverdi (2005) found a moderately weak relationship between a firm's ability to create, share, integrate, and use knowledge and financial performance. However, there have been little empirical studies that examine the relationships at the dimensional level with organizational performance. In addition, these studies mainly conducted in the private sector in the developed country context. Based up on the above theoretical and literature review, the following conceptual framework of the study was developed.

Figure 1: Conceptual Framework of the Study

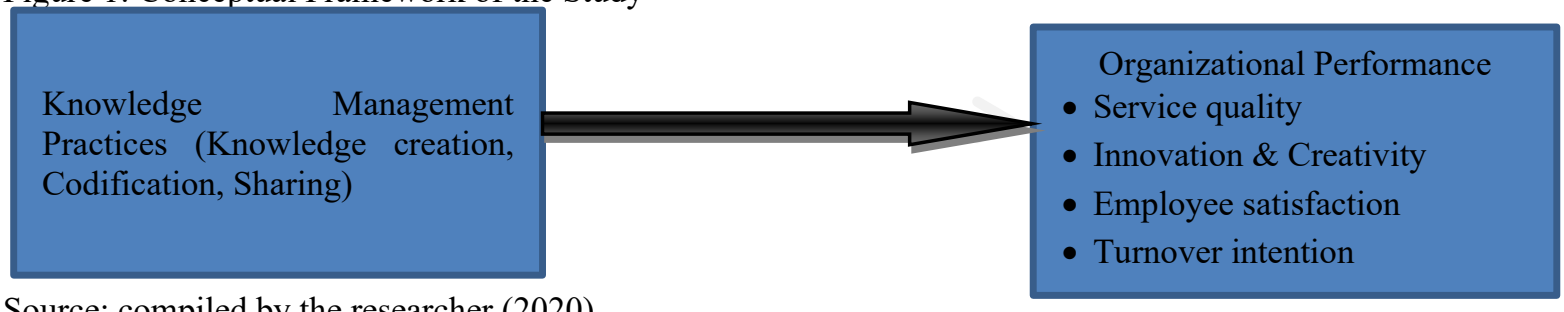

Source: compiled by the researcher (2020)

\section{Methodology}

\subsection{The study area and sampling procedure}

The current study will be undertaken in the SNNPR. Southern Nations, Nationalities, and Peoples' Region often abbreviated as SNNPR; is one of the nine ethnically based regional states, resulting from such restructuring, of Ethiopia. Its capital is Hawasa. SNNPR is divided in to14 zonal administrations, which, unlike the other regions, are institutionally separate from the regional government (thus, only the regional bureaus fall under the regional government). In addition, there are 4 special woredas. Sector ministries at federal level have their equivalent office at regional government level in the form of 40 public sectors bodies (bureaus, authorities, institutes and agencies) located at Hawassa, the capital. Public Service and Human Resource Development Bureau is one of these pectoral bureau found in Southern Nations Nationalities and Peoples Region (SNNPR). Hence, the study was conducted in Public Service and Human Resource Development Bureau in SNNPR state. A sample of 118 employees was selected out of 168 total employees by employing systematic random sampling.

\subsection{Data analysis}

The relationship between knowledge management practice and organizational performance was analyzed by using Pearson correlation and simple linear regression analysis. It is hypothesized that knowledge management practice 
will enhance organizational performance.

\section{Results and discussion}

In order to test the effect of knowledge management on organizational performance correlation and simple regression was performed. The results of both statistical diagnoses are presented and discussed as follows.

Table 1: Results of Correlation Analysis

\section{Results of Pearson Correlations}

\begin{tabular}{lllll}
\hline Research Variables & $\mathbf{1}$ & $\mathbf{2}$ & $\mathbf{3}$ & $\mathbf{4}$ \\
\hline Knowledge Identification & 1 & & & \\
\hline Knowledge Sharing & $.475^{* *}$ & 1 & & \\
\hline Knowledge Storage & $.232^{*}$ & $.348^{* *}$ & 1 & \\
\hline Organizational Performance & $.638^{* *}$ & $.554^{* *}$ & $.532^{* *}$ & 1 \\
\hline
\end{tabular}

**. Correlation is significant at the 0.01 level (2-tailed).

*. Correlation is significant at the 0.05 level (2-tailed).

Source: Field Survey (2020)

The above table demonstrates the result of Pearson correlation analysis between knowledge management practice and organizational performance. The correlation analysis was performed in order to examine the association between the two variables. Hence, as displayed in the table above, all knowledge management practices have a significant and positive relationship with organizational performance.

Table 2: Model Summary of Regression Analysis

Model Summary

\begin{tabular}{|l|l|l|l|l|l|l|l|l|l|}
\hline \multicolumn{1}{l|}{ Model Summary } \\
\hline
\end{tabular}

Source: Field Survey (2020)

Table 2 above illustrates the total explained variance in organizational performance by the practice of knowledge management. As it is shown in the table knowledge management practices have explained $60 \%$ of the variation in organizational performance $\left(R^{2}=.597, F(3,114)=56.205\right.$, at $\left.P<.001\right)$. This finding is consistent with the findings of Kiessling, et al., 2009 \& Fugate, et al., 2009). The result of ANOVA test was also significant as displayed in table 3 below.

Table 3: Results of ANOVA

\begin{tabular}{|c|c|c|c|c|c|c|}
\hline \multicolumn{7}{|c|}{ ANOVA } \\
\hline \multicolumn{2}{|c|}{ Model } & Sum of Squares & df & Mean Square & $\mathrm{F}$ & Sig. \\
\hline \multirow[t]{3}{*}{1} & Regression & 19.555 & 3 & 6.518 & 56.205 & $.000^{\mathrm{b}}$ \\
\hline & Residual & 13.221 & 114 & .116 & & \\
\hline & Total & 32.775 & 117 & & & \\
\hline
\end{tabular}

Source: Field Survey (2020)

ANOVA tests the null hypothesis that multiple ' $R$ ' in the population equals 0 . As shown in the table, the model reaches statistical significance $($ Sig. $=.000)$.

Table 41: Results of Linear Regression Analysis

\begin{tabular}{|c|c|c|c|c|c|c|}
\hline \multicolumn{7}{|c|}{ Coefficients $^{\text {a }}$} \\
\hline \multirow{2}{*}{\multicolumn{2}{|c|}{ Model }} & \multicolumn{2}{|c|}{ Unstandardized Coefficients } & \multirow{2}{*}{$\begin{array}{l}\text { Standardized Coefficients } \\
\text { Beta }\end{array}$} & \multirow[b]{2}{*}{$\mathrm{t}$} & \multirow[b]{2}{*}{ Sig. } \\
\hline & & $\mathrm{B}$ & Std. Error & & & \\
\hline \multirow[t]{4}{*}{1} & (Constant) & 1.012 & .186 & & 5.445 & .000 \\
\hline & Knowledge Identification & .350 & .052 & .454 & 6.697 & .000 \\
\hline & Knowledge Sharing & .167 & .054 & .216 & 3.076 & .003 \\
\hline & Knowledge Storage & .266 & .048 & .351 & 5.519 & .000 \\
\hline
\end{tabular}

a. Dependent Variable: Organizational Performance

Source: Field Survey (2020)

The table above (table 4) shows the result of standardized and unstandardized regression coefficients for predicting organizational performance by knowledge management practices. Consequently, based on the result shown in the table, knowledge identification / creation/ practices significantly influence organizational performance $(\beta=.35, P<.001)$. Knowledge storage /documentation/ practices have also a significant effect on organizational performance with a beta value of $(\beta=.266, P<.001)$. Although the effect of knowledge sharing 
practices on organizational performance achieved statistical significance $(\beta=.167, P<.005)$, the impact was not high when compared with the previous two predictors. This finding is against the literature which declares knowledge sharing as the heart of knowledge management (Bratianu \& Bolisani, 2015).

\section{Conclusion and Recommendations}

The aim of this study is to examine the influence of knowledge management practice on organizational performance. The data used for this study was collected from employees of Public Service and Human Resource Development Bureau (SNNPR, Ethiopia) with the total sample size of 118. The correlation and regression result revealed that knowledge management practice has a positive effect on organizational performance where it explains $60 \%\left(\left(\mathrm{R}^{2}=.597, \mathrm{~F}(3,114)=56.205\right.\right.$, at $\left.\mathrm{P}<.001\right)$. similarly, the result shows that all knowledge management practices significantly and positively influences organizational performance. Based on the results, knowledge creation practices significantly influence organizational performance followed by knowledge codification practices. However, the effect of knowledge sharing practices on organizational performance achieved statistical significance though it has lower effect compared with the previous two practices.

Implementing knowledge management system will play a key role in enhancing organizational performance in the public sector. Hence, Organizations can use the results of the study to be cognizant of the range of knowledge management practices practices in terms of their relative contribution to organizational performance.

\section{References}

Becerra-Fernandez, I., \& Sabherwal, R. (2014). Knowledge management: Systems and processes: Routledge.

Bratianu, C., \& Bolisani, E. (2015). Knowledge strategy: An integrated approach for managing uncertainty. Paper presented at the Proceedings of the 16th European conference on Knowledge Management.

Choi, B., Poon, S. K., \& Davis, J. G. (2008). Effects of knowledge management strategy on organizational performance: A complementarity theory-based approach. Omega, 36(2), 235-251.

Eftekharzadeh, R. (2008). Knowledge management implementation in developing countries: An experimental study. Review of Business, 28(3), 44.

Fiseha, M. (2015). Building a Knowledge Model: The Case of Ethiopian Revenue and Customs Authori. Addis Ababa University.

Hoskisson, R.E., Eden, L., Lau, C.M., \& Wright, M. (2000). Strategy in emerging economies. Academy of Management Journal, 43(3), 249-267.

Irma Becerra-Fernandez, R. S. (2001). Organizational knowledge management: A contingency perspective. Journal of management information systems, 18(1), 23-55.

Khan, A. M. (2010). Effects of human resource management practices on organizational performance: An empirical study of oil and gas industry in Pakistan. European Journal of Economics, Finance and Administrative Sciences, 24, 157-174.

Kianto, A., Ritala, P., Spender, J.-C., \& Vanhala, M. (2014). The interaction of intellectual capital assets and knowledge management practices in organizational value creation. Journal of Intellectual capital, 15(3), 362375.

Mohayidin, M. G., Azirawani, N., Kamaruddin, M. N., \& Margono, M. I. (2007). The application of knowledge management in enhancing the performance of Malaysian universities. Electronic Journal of Knowledge Management, 5(3).

Omar Sharifuddin Syed-Ikhsan, S., \& Rowland, F. (2004). Knowledge management in a public organization: a study on the relationship between organizational elements and the performance of knowledge transfer. Journal of knowledge management, 8(2), 95-111.

Oyemomi, O., Liu, S., \& Neaga, I. (2014). The contribution of knowledge sharing to organizational performance and decision making: A literature review. In Decision support systems iv-information and knowledge management in decision processes (pp. 1-12). Springer, Cham.

Tanriverdi, H. (2005), "Information technology relatedness, knowledge management capability, andperformance of multi-business firms"',MIS Quarterly, Vol. 29 No. 2, pp. 311-34

Yalew, T. (2011). Assessment of knowledge sharing practices of health care professionals in hospitals under Addis Ababa health bureau. Addis Ababa University.

Yu, S.-H., Kim, Y.-G., \& Kim, M.-Y. (2004). Linking organizational knowledge management drivers to knowledge management performance: An exploratory study. Paper presented at the 37th Annual Hawaii International Conference on System Sciences, 2004.

Zack, M., McKeen, J., \& Singh, S. (2009). Knowledge management and organizational performance: an exploratory analysis. Journal of knowledge management.

Zheng, W., Yang, B., \& McLean, G. N. (2010). Linking organizational culture, structure, strategy, and organizational effectiveness: Mediating role of knowledge management. Journal of Business research, 63(7), 763-771. 